\title{
„Mert öleléssel kezdődik”. A gyermekek szexuális zaklatásának reprezentációja kortárs magyar és külföldi filmekben
}

\begin{abstract}
Absztrakt
Jelen dolgozatban a gyermekek szexuális zaklatásának reprezentációját vizsgáljuk a külföldi és magyar filmekben, olyan elemzési szempontok mentén, mint az ügyben résztvevő felek nézôpontjainak narratív múködtetése, az intézményi, családi felelősségvállalás bemutatása és az esetleges állásfoglalás megjelenése. Elôször a külföldi filmek reprezentációs módjait vizsgáljuk, így $A$ vadászat, a Kétely és $A$ történet címú filmeken keresztül próbáljuk bemutatni a zaklatás - és fôként az abból eredô következmények - eredményes feldolgozási lehetôségeit. Ezután ugyanazon szempontok mentén a magyar filmekben is áttekintjük a téma megjelenítését; az elemzés középpontjába a Szép csendben címú, 2019-ben készült film kerül. Ugyanakkor tágabb kontextusban a Remélem legközelebb sikerül meghalnod :) és a FOMO - Megosztod és uralkodsz címú filmeket is megvizsgáljuk, mivel azok jól - és különböző módokon - egészítik ki a fiatal korosztályban történô bántalmazás témájának magyar feldolgozását. A filmes példák vizsgálatán keresztül így látható lesz, milyen alternatívákkal dolgoznak az egyes alkotók, és hogyan helyezhetô el ebben a tendenciában a tanulmány fókuszát adó Szép csendben címú film. Az összevetés során feltûnô konklúzió, hogy a külföldi alkotások - a magyar filmekkel ellentétben - nem a téma érzékeny kezelésével kísérleteznek, hanem komplex narratívákon keresztül mélyebb kontextust is igyekeznek megteremteni, egyfajta tézist, állásfoglalást is kifejezve.

\section{Szerzô}

Oláh Renáta 1997-ben született Kistarcsán. 2021-ben szerzett alapszakos diplomát az ELTE Bölcsészettudományi Karán szabad bölcsészet szakon, filmelmélet és filmtörténet specializáción. Jelenleg a Budapesti Metropolitan Egyetem animáció mesterszakán tanul. E-mail: olah.renata97@gmail.com
\end{abstract}

Varga Bence 1998-ban született Budapesten. 2021-ben szerzett alapszakos diplomát az ELTE Bölcsészettudományi Karán szabad bölcsészet szakon, filmelmélet és filmtörténet specializáción. 
Jelenleg az ELTE BTK filmtudomány mesterszakán tanul.

E-mail: v.bence1998@gmail.com

https://doi.org/10.31176/apertura.2021.16.4.9 


\section{„Mert öleléssel kezdődik”. A gyermekek szexuális zaklatásának reprezentációja kortárs magyar és külföldi filmekben}

A gyermekek szexuális zaklatásának tematizálása igen eltérô a magyar, illetve külföldi filmekben, különböző oldalakról és mélységben bemutatva a problémát. Célunk egyrészt összehasonlítást adni a kortárs hazai és külföldi filmek feldolgozási útjai, módjai között, másrészt sikeres és elismert nemzetközi filmes példákkal rávilágítani azokra a múködô narratív-dramaturgiai és stilisztikai megoldásokra, melyek a magyar példákkal szemben hatásossá és hitelessé tudják tenni a témában készült alkotásokat. A magyar filmeken belül is kiemelt fókuszt kap a Szép csendben (Nagy Zoltán, 2019) címú alkotás, mely szorosan véve dolgozza fel az intézményi zaklatás kérdését, jó alapot adva a külföldi filmekkel való összehasonlításra. Hipotézisünk így az, hogy a Szép csendben címú film erôs dramaturgiai-narratív eszköztárból dolgozik, azonban mégsem tud kellôen elmélyülni a zaklatás témájában. Ennek oka, hogy egyik szerep, egyik oldal nézôpontja sincs igazán kibontva a narratív szálak szintjén, illetve a zaklatást övezô társadalmi reakciók és következmények is elmosva, lebegtetve jelennek meg, részben a furcsán nyitott vég miatt. A probléma kétrétû: ezzel a megközelítéssel a film egy nagyon fontos, aktuális és megosztó kérdésben nem foglal állást, a sejtetésekkel további találgatásoknak és félreértéseknek nyitva utat; másfelôl a lebegtetés ahhoz nem elég erôteljes, markáns, hogy a zaklatási helyzet és a résztvevókben kialakuló feszültséget valódi drámaiságában, árnyaltan átadja.

\section{A gyermekek szexuális zaklatásának definiálása és reprezentációs módjai}

Mindenekelôtt fontos meghatározni a gyermekek szexuális zaklatásának definíciós kereteit, hogy a filmben való reprezentációt már bizonyos kulcsfogalmak ismeretében tudjuk vizsgálni. A szakirodalom áttekintésekor rögtön feltûnhet, hogy valójában nincsen egyértelmú, konszenzusos meghatározás a gyermekek szexuális zaklatására. A legtöbb szöveg a bántalmazott életkorából indul ki, azonban kulturális, társadalmi, politikai és vallási tényezôktôl függóen is változhat, hogy jogi értelemben hány éves kortól beszélhetünk szexuális interakcióba való kölcsönös beleegyezésrôl (age of consent) ${ }^{[1]}$. Jelen esetben a zaklatás egy igen specifikus formájáról beszélünk, amely alapvetôen a kiskorú személlyel folytatott szexuális tevékenységeket foglalja magába, és nem feltétlenül tartalmaz fizikai kontaktust. ${ }^{[2]}$ Julia C. Davidson, kriminológiai professzor szerint a jelenség bármilyen definiálásakor fontos figyelembe venni az áldozat 
perspektíváját is, felismerve a tényt, hogy a legtöbb esetben a zaklatás jelentôs károkat okoz az elszenvedôben. ${ }^{[3]} \mathrm{Az}$ áldozatok esetében ugyanis jóval nagyobb a mentális betegségek (függôségek, öngyilkossági hajlam, depresszió, szorongás, poszttraumás stressz szindróma) és labilis (pár)kapcsolatok esélye. ${ }^{[4]}$ Edward L. Rowen, amerikai pszichiáter szerint a gyermekek szexuális zaklatása nem feltétlen esik egybe a pedofília fogalmával, mert az elóbbi valójában egy társadalmi konstrukció, amely azon alapszik, hogy egy felnôtt és egy gyerek közti szexuális kontaktus minden esetben etikailag helytelen. ${ }^{[5]}$ Az elkövetô ugyanis visszaél a gyermeki gyengeséggel, hatalmat gyakorolva az áldozat felett, aki gyakran alacsony önértékeléssel, gyenge családi kapcsolatokkal vagy kevés baráttal rendelkezik, ${ }^{[6]}$ így kiszolgáltatottságuk miatt a kiskorúak kiemelten veszélyeztetett csoportot képeznek.

Felmerülhet a kérdés, hogy egy ilyen esetben milyen szerepet vállal a gyermeket körülvevô család és közeg. Egyes statisztikák szerint a társadalmilag elszigetelt, instabil, diszfunkcionális családban élô, a mozgássérült, az egy szülôvel - vagy kifejezetten mostohaapával - nevelkedô gyermek például nagyobb eséllyel válhat szexuális zaklatás áldozatává. ${ }^{[7]}$ Az erre irányuló, vegyes eredményeket mutató kutatások alapján azonban nem lehet egyértelmú konklúziókat levonni, ugyanis az erôs családi kapcsolatok megléte sem feltétlen jelent biztonságot a gyerek számára, sôt, a zárt közösségekból olykor nehezebben is kerülhetnek nyilvánosságra az ilyen esetek. Így például azokban a családi környezetekben, melyekben az abszolút hatalmat a megkérdőjelezhetetlen férfi tekintély képviseli, nagyobb valószínúséggel fordul elô zaklatás, amely gyakran fizikai, érzelmi és/vagy szexuális módokon nyilvánul meg. ${ }^{[8]}$ A hetvenes évek feminizmusával elôtérbe kerülő nemi elnyomás fogalma is a szexuális bántalmazás magyarázatául szolgálhat. A ház fejeként ugyanis a férfi ezekben az esetekben a szexuális hatalmon keresztül definiálja saját szexualitását, felhatalmazva magát, hogy dominanciát gyakoroljon a gyengébbekkel, például az anyával vagy éppen a gyermekkel szemben. ${ }^{[9]}$

A hatalom - és az azzal való visszaélés - tehát rendkívül fontos tényezóként jelenik meg a zaklatási ügyekben, mely sokszor intézményes vagy szervezeti keretek között valósul meg. Az „intézményi zaklatás" (institutional abuse) kifejezés elsôsorban a 90-es évek második felétôl került egyre inkább a közérdeklődés fókuszába, mely jól tükröződött a katolikus egyházat hirtelen megrázó szexuális botrányok vizsgálatában is. ${ }^{[10]}$ Így például az egyház kiemelten fontos szereplôként van jelen a kortárs zaklatási botrányokban, ez azonban gyakorlatilag minden hierarchikusan felépülô nevelôoktató intézményre igaz lehet, ugyanis azok olyan közeget teremthetnek meg, amelyben a gyermek „alárendelt” félként kiszolgáltatottá tud válni az ôt oktató-nevelő felnôttnek. Ez az egyenlôtlenség természetesen normális keretek között nem generál elnyomást és a hatalom kihasználását, ugyanakkor leggyakrabban mégis ezekben a viszonyrendszerekben fordulnak elô az abúzus különféle formái. A családban történô zaklatás is az egyenlôtlenségből és alárendeltségbool ered, mely során a szülói vagy rokoni tekintély szolgáltatja az elnyomás alapját, az intézményi zaklatáshoz hasonlóan. Itt fontos megemlíteni azt a tényt is, hogy a gyermek sok esetben olyan személy áldozatául esik, akit ismer, netán a család tagja is egyben. ${ }^{[11]}$ Mindezek tanulmányozása azért is lényeges, mivel az intézményi-szervezeti szerepvállalás (vagy éppen annak hiánya), 
valamint az adott közeg reakciója központi elemeit adják a téma filmben való megjelenítésének.

A gyermekek szexuális zaklatásának reprezentációja két csoportra osztható: egy adott esettel foglalkozó ábrázolásra (epizodikus), illetve az átfogóbb, személyek helyett a problémát vizsgáló megjelenítésre (tematikus). A médiában az elsô kategória a gyakoribb, mert egy személyes történet jobban megrázza a befogadót, mivel az közvetlenül az érzelmekre hat, még ha így nem is születik hiteles és teljes körú ábrázolás a probléma egészérôl. Egyrészt befolyásoló erôvel bír, hogy kirôl mit és mennyit mutatnak be, másrészt a sajtóban ezeket az eseteket (is) szélsôségesen helyezik el a jó és rossz skáláján. A gyerekekhez a legkönnyebb olyan jellemzőket társítani, mint az „ártatlanság”, „passzív elszenvedô”, olyasvalaki, aki „nem tudja megvédeni magát”, így ốk ideális áldozatok. Nils Christie, norvég szociológus és kriminológus azokra érti ezt a kifejezést (ideal victim), akik gyengébbek az elkövetôvel szemben, morálisan nem kérdôjelezhetôk meg a búncselekmény megtörténtekor, nem okolhatók a történtekért, és így a tettes egyértelmúen vétkes. ${ }^{[12]}$ Bár az ideális áldozat csoportjába beleesnek a fiúk és a színes bôrú gyermekek is, ốk mégis alulreprezentáltak, ezáltal az tükröződik a médiából, hogy szinte kizárólag lányokkal történik szexuális zaklatás. A média sztereotipizálása a zaklató személyét is érinti, akit a leggyakrabban a többi embertől elkülönítve „állatként” vagy „szörnyetegként” neveznek meg és ábrázolnak, ${ }^{[13]}$ holott az újabb szakirodalmak igen nagy hangsúlyt fektetnek a zaklató személyének árnyaltabb feltárására, belevéve azt a tényt is, hogy nem csak férfiak lehetnek elkövetôk.

Anne M. Nurse, amerikai szociológus szerint a gyermekek szexuális zaklatását tekintve négy fó attribútum határozható meg, melyek utalnak az elkövetô lehetséges motivációira is. Az elsô kategóriában az abuzálót pedofilként határozhatjuk meg - mely az illetố szexuális orientációjára irányul -, a második szerint a zaklatást a tettes mentális betegsége váltja ki, a harmadik esetben az elkövetô saját szándékos döntéséből eredôen bántalmaz kiskorút, míg a negyedik jellemző a felnôtt saját korábbi áldozattá válásával magyarázza a cselekedetet. [14]

Fontos lehet továbbá röviden áttekinteni, miként került be egyre inkább a köztudatba a gyermekek szexuális bántalmazásának jelensége, mely természetes módon magával vonzotta a téma médiában és filmben való megjelenítését. Egészen a 70-es évekig a gyermekbántalmazás esetei szinte semmilyen módon nem kerültek megosztásra a nyilvános térben, a kiskorún elkövetett szexuális erôszak pedig még nem vált társadalmilag aggasztó jelenséggé. A 70-es évek nyilvánosságában már nem elszigetelt esetekként kezelték a gyermekek ilyen típusú kihasználását, hanem rendszerszintú szociális problémaként, mely a szervezeti-intézményes gyermeknevelés és gyermekvédelem kudarcát is felvetette. Ez vezetett odáig, hogy a 90-es években a már említett „intézményi bántalmazás” valóban meghatározó problémává kezdett válni, emellett a „múltbéli bántalmazás" (historical/non-recent abuse) fogalma is megjelent, mely a gyermekkorukban abuzált felnôttek egyre gyakoribb felszólalásai alapján jelent meg. A téma iránti nagyobb médiafigyelem a 80-as évektôl figyelhetô meg, kezdetben a családon belüli erôszakot helyezve a fókuszba. ${ }^{[15]}$ Az egyre nagyobb számban felszínre kerülố esetek miatt a média nagyon fontos szerepet játszott a probléma közbeszéd szintjén való nyíltabb megjelenésében, illetve az emberek 
téma iránti érzékenyítésében és informálásában. ${ }^{[16]}$

Ezzel párhuzamosan a filmekben való reprezentáció is jelentôs változáson ment keresztül. Todd Taylor idôszakokra bontva vizsgálja a fiúgyermekek szexuális bántalmazásának megjelenését a filmben, mely során megállapítja, hogy az 1967 és 1988 közötti filmek esetén leginkább „comingof-age" narratívákba öltve jelenik meg a probléma, melyekben a cselekvőképes és aktív kiskorú szemszögén keresztül látjuk az eseményeket, és amelyekben a felnôtt nem feltétlen jelenik meg szörnyetegként. ${ }^{[17]}$ A 80-as évek közepétôl azonban egy új narratív trend jelent meg, mely a fôszereplô szemtanúfunkcióját helyezte a középpontba, ez elsôsorban tévéfilmekben, majd különböző mozifilmekben volt jellemző 1985 és 2006 között. ${ }^{[18]}$ A zaklatást szemtanúként vagy külső megfigyelôként megtapasztaló szerep valóban erôsen dominánssá válik a kortárs alkotásokban is, erre látunk a késôbbiekben vizsgált filmeknél is példát. Így elôször érdemes a téma kortárs külföldi filmben való feldolgozási módjait megvizsgálni, majd az azok által felvetett szempontokat áttekinteni a magyar filmes reprezentációban is, a fố hangsúlyt a Szép csendben címú filmre fektetve.

\section{A zaklatás megjelenése kortárs külföldi filmekben}

Érdemes elôször a gyermekek szexuális zaklatásának kérdését tágabb, nemzetközi filmes kontextusban megvizsgálni, hogy láthatóvá váljanak a téma feldolgozásának alapvetô narratív és stilisztikai alternatívái. Ezáltal fontos lesz áttekinteni az áldozat-elkövetô-kívülálló hármasának pozícióit, a lehetséges hangsúlyokat és közelítési módokat, valamint a filmekben megjelenô kulturális és közegbeli sajátosságokat. Mindezt három kortárs filmpéldával szemléltetjük. $\mathrm{Az}$ amerikai Kétely (Doubt. John Patrick Shanley, 2008), a dán A vadászat (Jagten. Thomas Vinterberg, 2012) és a szintén amerikai $A$ történet (The Tale. Jennifer Fox, 2018) más-más módon és hangsúllyal szövik bele a narratívába az abúzust. A Kétely és $A$ vadászat így inkább a vélhetô szexuális bántalmazást követô reakciókat és társadalmi mechanizmusokat emeli ki, míg $A$ történet inkább a konkrét, múltban történô traumát és a zaklatásra való visszaemlékezést helyezi fókuszba.

Ugyanakkor mindhárom film felvet olyan kérdéseket és problémákat, amelyeket a bevezetésben tárgyalt szociálpszichológiai kulcsfogalmak is nevesítettek, így ezek a filmek képet adhatnak arról, hogyan lehet a zaklatás kényes témáját hiteles és összetett módon ábrázolni. A fejezet fô szempontjait a karakterek szerepei és a hozzájuk való igazodás, a hatalmi hierarchia és intézmény szerepe, valamint az állásfoglalás módjai adják, melyek igen sokszínú reprezentációs képeket rajzolnak ki a három filmet tekintve.

Szerepek és nézópontok

Az áldozat-elkövetô-kívülálló hármasát tekintve megállapítható, hogy a vizsgált filmek különféle egyénekre és szerepekre helyezik a hangsúlyt, mely sokszor befolyásolja a téma feldolgozásának mélységét is. A tárgyalt filmekben ugyanis árnyaltan kerül bemutatásra a történések egyénre és 
közegre gyakorolt hatása, részben azért, mert azok több nézôpontot is hatásosan múködtetnek egyszerre - ilyen $A$ vadászat és Kétely -, vagy pedig a trauma szubjektív megélésére helyezik a hangsúlyt (erre példa $A$ történet). Mindazonáltal jelen filmek esetében is olykor nehéz elkülöníteni a személyes és az objektív, több nézôpontból megmutatott perspektívát, ez fôkként $A$ vadászat esetén problematikus, ahol egy kiemelt fôszereplöhöz - a vélt elkövetőhöz - igazodunk a film nagy részében, egyúttal azonban az áldozat és a kívülálló nézôpontja is megjelenik a cselekményben. Így felállítható egyfajta skála a három film narratív nézốpontjait tekintve, melyben a Kétely a több perspektívára, $A$ vadászat az egy kiemelt nézôpont mellett megjelenô több szemszögre, $A$ történet pedig a teljesen szubjektív narrációra mutat példát.

A Kételyben a narratíva szintjén egy - vagy még inkább több - kívülálló személy szemén keresztül kerül bemutatásra a zaklatás és annak következményei. John Patrick Shanley filmje azonban elrugaszkodik a konkrét történéstôl, és inkább az egyházi struktúráról, a hatalom gyakorlásáról, valamint a fegyelem és rend elsôbbségérôl szól, ${ }^{[19]}$ miközben a személyes felelôsség kérdését feszegeti különféle karakterek nézôpontján keresztül. A film története - mely az író-rendezô azonos címú drámáját dolgozza fel - 1964-ben, egy bronxi katolikus iskolában játszódik, ahol a szabadabb szellemiséget képviselô Flynn atya kezd gyanússá válni az iskola vaskezú igazgatónôje, Aloysius Beauvier nôvér számára, mivel a pap feltûnôen jó viszonyt alakít ki az egyik diákkal, aki nem mellesleg az iskola elsô színes bőrú tanulója. A nővér ugyan nem tud valódi bizonyítékokat felmutatni, azonban hitének erejével áll szembe Flynn atyával, miután az ártatlan James nôvér felhívja figyelmét a bensőséges pap-növendék viszonyra.

Először is fontos leszögezni, hogy a film nem ad valódi bizonyságot a nézônek arról, hogy a zaklatás valóban megtörtént-e, valószínûsíthetôen Aloysius nôvér vádja hamisnak bizonyul, a film végén ezt már a nô is egyre inkább érezni kezdi. Így a Kétely nem is mutatja meg a zaklatást semmiféle explicit módon, csak utal a nôvérek által látott, könnyen félreérthetô jelekre, melyek a gyanú alapjául szolgálnak. A karaktereket és szerepeket tekintve a klasszikus értelemben vett „áldozatként” az említett diákot, Donald Millert lehet megnevezni, aki azonban szinte alig jelenik meg a történetben, ami rámutat, hogy a film nem a gyermek szexuális zaklatásának konkrét eseményét dolgozza fel, hanem az azt követô és körülvevô erkölcsi dilemmákat. Donald egyedüli színes bőrúként az iskolában, valamint - anyja elmondása alapján - homoszexuálisként többszörösen hátrányos és kiszolgáltatott helyzetben van, éppen ezért karolja fel ôt Flynn atya, ami a nôvér számára a vád alapját adja. A fiú tehát abszolút beleesik a Nils Christie által ideális áldozatnak hívott kategóriába, továbbá egy alulreprezentált réteget mutat meg a színes bôrú fiúgyermek személyében.

A feltételezett elkövetô a történetben Flynn atya, aki azonban a történet előrehaladtával inkább az áldozat funkcióját tölti be, ahogyan Aloysius nôvér egyre eltökéltebb hadjáratot indít ellene. A férfit így végül egy másik templomba helyezik, egy magasabb pozícióba, mely egyfelól a férfi elleni vádak negatív következményeként értékelhetô, ugyanakkor az egyház ijesztôen közömbös hozzáállását is példázza a zaklatás botrányával kapcsolatban. A kívülálló Aloysius nôvér szerepe egyértelmúen a leghangsúlyosabb a narratívában, ô ugyanis kívülrôl látja a történteket, és kezd el 
vádaskodni apró, kétértelmú jelek alapján. A nô személyének ábrázolása egyúttal segít megérteni azt a tekintélyelvú pozíciót, melyet egyébként sok püspök képvisel a zaklatási ügyek esetén. [20] Emellett ott van „ellenpólusként” a fiatal James nôvér is, aki ugyan maga indítja el egy óvatos feltételezéssel a botrányt, azonban késóbb ố is egyre szkeptikusabban nézi az atya elleni rágalmazást. Kívülállóként így inkább az ô szemszögével tud a nézô szimpatizálni, a nô ugyanis az események elôrehaladtával folyamatosan képes átértékelni előfeltevéseit, pont ahogyan a nézô is teszi a látottak közben. Így egyfelôl a filmben megjelenố kettôs kívülálló-szemszög alátámasztja a filmes reprezentációknál már elôkerülő szemtanúfunkció (witnessing) felerôsödését, másfelôl a Kétely ezáltal igen komplex módon képes egy feltételezett abúzus - egyházi-iskolai közegben való - megítélését körbejárni.

$A$ vadászat címú filmben is fellelhetô mindhárom nézôpont, ugyanakkor sokkal kevésbé explicit módon, elsôsorban itt is csak a vélt elkövetôre helyezve a hangsúlyt. A történet egy kis dán faluban játszódik, ahol Lucast 【az elvált, jó családapaként és a közösség megbecsült, tagjaként számontartott óvodai dolgozót [egy kislány, Klara füllentése miatt szexuális zaklatással vádolnak meg. A terjedô hír hallatán addigi barátai és az egész város fokozatosan elfordulnak tôle, majd rátámadnak a férfira, aki mellett csak néhány barátja és fia, Marcus marad. Jelen esetben a film során megtudjuk nézóként, hogy a fôszereplô nem követett el semmit a vádakat elindító kislány ellen, és így az abúzus ténye valójában csak egy gyermeki elszólásból eredő félreértés következménye. Éppen ezért $A$ vadászat szintén a zaklatás hírét követố társadalmi mechanizmusokra helyezi a hangsúlyt, vagyis a bensôséges közeg reakcióját mutatja meg, amint az kegyetlenül kiveti magából egyik tagját.

Az „áldozat” tehát Klara, a kislány lesz, akinek életébe betekintést nyújt a film, már csak azáltal is, hogy a lány apja, Theo, Lucas barátja. Így a nézó tudja, hogy a kislány valójában teljesen egészséges bizalmi viszonyt ápol Lucassal, csak meggondolatlanul beszél ellene, amikor szexuális molesztálásra utaló jeleket ad az óvodát vezetô Grethének. A kislány ennek következményeit látva próbálja meggyőzni a felnôtteket, hogy nem mondott korábban igazat, azonban ekkor már késô, elindul a Lucas elleni rágalmazás. Az áldozat szerepe gyakorlatilag ennyiben kap helyet a narratívában, ugyanis ezután inkább az ôt és Lucast körülvevô közeg reakcióját látjuk kibontakozni. Az „elkövetô” az ártatlan Lucas, akivel éppen azért tudunk nézôként erôsen szimpatizálni, mivel tudjuk, hogy nem igazak az ốt érô vádak, így - Flynn atyához hasonlóan - ô is elkövetôből válik áldozattá. A Lucashoz való igazodás egyúttal új aspektust hoz be a téma feldolgozásába, ugyanis a férfi fôszerepbe helyezése által befogadóként megtapasztalhatjuk a zaklatási botrányok másik oldalát, vagyis a megvádolt személy perspektíváját is. $A$ vadászatban is felmerül a kívülálló személy funkciója és felelôssége, ezt elsôsorban a botrányt elindító Grethe, Klara apja és egyben Lucas barátja, Theo és Lucas fia, Marcus képviselik. Közülük talán Theo van a legproblémásabb helyzetben, aki - mivel lányáról van szó - kíméletlenül Lucas ellen fordul, azonban a gyúlölet eluralkodása után barátként is próbál a férfiért tenni. Az ő karaktere önmagában megmutatja, milyen problematikus az állásfoglalás egy ilyen esetben, amikor a kívülálló személy az áldozat oldalán áll, de jól is ismeri az elkövetôt. Emellett Marcus, Lucas fia is nagyon fontos szerepet kap a 
narratívában, ugyanis a fôszereplôtôl függetlenül is látjuk, amint a fiú küzd apja igazáért, még ha családi barátokkal is kell emiatt összetúzésbe keverednie. Fontos emellett azonban kiemelni, hogy a filmben a kívülálló-szemtanú szereplők nem tudják objektív módon megítélni az eseményeket, mivel azok családi-emocionális okokból alapvetôen valamelyik oldalt képviselik. Mindazonáltal $A$ vadászat szintén sokrétú módon mutatja be egyrészt a - sztereotipikus zaklató képével szembemenô - vádlottban lejátszódó lelki folyamatokat, másrészt pedig a kívülállóként ítélkezô emberek egymást felbujtó reakcióját.

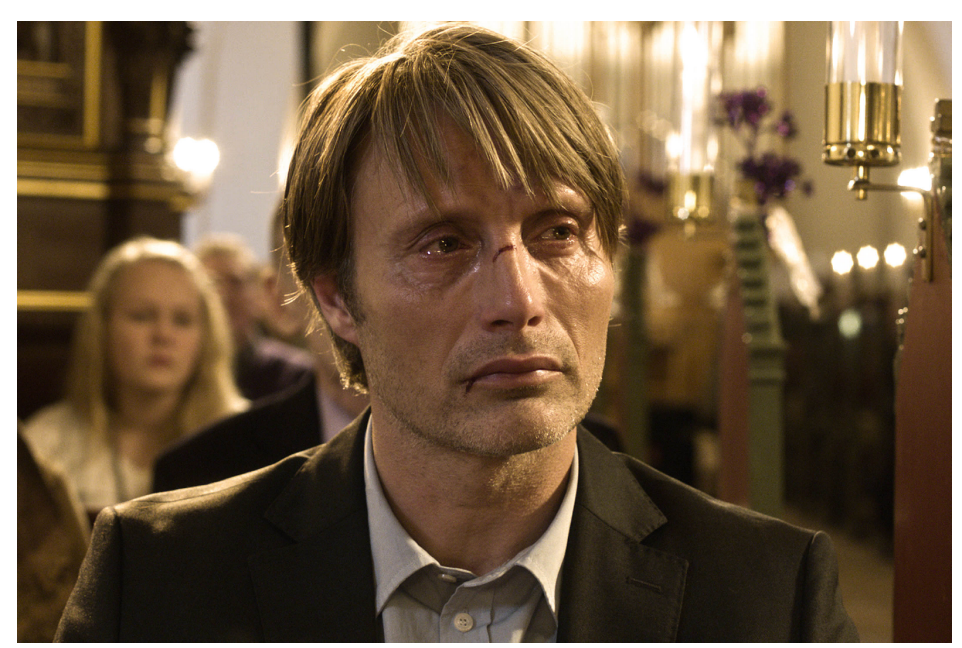

A vadászat (Jagten. Thomas Vinterberg, 2012)

A történet címú film teljesen eltérô narratív eszközökkel él, mint az előbb tárgyalt két alkotás.

Jennifer Fox filmje ugyanis egy konkrét, önéletrajzi ihletettségú történetbôl indul ki, mely nagyon erôsen szubjektív narrációt alkalmaz, és amelyben a gyermeket érô szexuális zaklatás kifejezetten explicit módon jelenik meg. Ennek ellenére a film nagyon finom képi világgal dolgozik, az áldozat perspektívája pedig bravúros filmnyelvi-stilisztikai megoldásokkal kerül bemutatásra.

A rendezőnô a saját életének traumáját feldolgozó filmben az azonos nevet viselô, újságíróprofesszor Jennifer élete felborul, amikor anyja egy tizenhárom évesen írt levelét megtalálja, melyben két felnôtt edzójével való bizarr viszonyáról ír. A már felnôtt nô a leveleket visszaolvasva próbálja feleleveníteni a múltat, ráeszmélve, hogy a gyerekként elfogadott, mára eltemetett szexuális viszony mély traumaként él benne. Itt fontos megemlíteni az elfojtott emlékezet jelenségét, mely során a traumatikus eseményeket elszenvedô egyének védekezésképp öntudatlanul is elnyomják a múlt emlékeit, ${ }^{[21]}$ ezt próbálja ugyanis feloldani a film során a főszereploonô. Így A történet a már említett, kilencvenes években egyre nagyobb fókuszt kapó „múltbéli bántalmazás” (historical/non-recent abuse) jelenségét és annak konkrét múködését járja körbe. Következésképp a film középpontjában az áldozat perspektívája áll, aki az események felidézésével folyamatosan felülírja a múltat, így ennek a tudati-emlékezeti folyamatnak a múködését látjuk vizuálisan megjelenni filmen. A zaklatás reprezentációját vizsgálva alapvetôen megállapítható, hogy a felnôttek által narrált történetekben a gyermeki én is állandóan jelen van a múlt átható lenyomataként, így a gyermekkori trauma általában nagyban formálja a késóbb kibontakozó életet, ${ }^{[22]}$ mely „áthatást” A történet vizuálisan is erôsen szemléltet. Emellett az áldozati nézôpont 
dominanciája által erôsen jelen van a filmben a bevezetésben is említett „coming-of-age”narratíva, ennélfogva a gyermek felnövésének és önismeretének folyamata is hangsúlyt kap a cselekményben. Jennifer ugyanis visszatér gyerekkori emlékeihez, és annak jelentôsebb fordulópontjaihoz, hogy ezáltal megértse fiatalkori énjét, ezen keresztül pedig az ôt ért eseményeket. Ez ugyanakkor kifejezetten nehéz feladatnak bizonyul, melyet érzékeltetnek az önmagával folytatott viták többször előkerülô jelenetei is.

Az áldozati nézôpont tehát igen összetett és mély módon kerül bemutatásra, mely mellett csak finoman, szinte alig mutatkozik meg az elkövetô(k) perspektívája. Mrs. G. és Bill idôskori megjelenései ugyanakkor fontos pontjai lesznek a narratívának, ${ }^{[23]}$ mivel ekkor szembesül vele Jennifer, hogy mindkét személy túllépett a történteken, szinte úgy tesznek, mintha nem is létezett volna a köztük lévô viszony. A zaklatók felelôsségvállalásának hiánya a kutatásokban szintén gyakran elôkerül, ${ }^{[24]}$ és a vizsgált alkotásban is hangsúlyos. A szubjektív elbeszélés ellenére ugyanakkor a kívülálló szerep is megjelenik az anya karakterén keresztül, aki a levél megtalálásával maga indítja el a fôszereplőnóben lejátszódó folyamatot. Ezen felül ahogyan Jennifer anyja magát is felelôssé teszi a történtekért, a szülői felelôsség kérdése is felvetôdik, ami szintén árnyalja a múltban történô események megítélését. Az áldozathoz való igazodással ugyanakkor arra is rávilágít a film, hogy egy kívülálló számára - még ha nagyon közeli családtag is - mennyire nehéz megérteni az áldozatban lejátszódó mentális folyamatokat és motivációkat. A történet tehát rendkívül hatásosan tudja múködtetni az áldozatot fókuszba helyezố narratívát, melyben szándékosan csak kevésbé nyomatékosan jelennek meg az elkövetôk és a kívülálló szerepei, meghagyva a hangsúlyt a múltbéli trauma jelenben való személyes feldolgozásán.

\footnotetext{
A közeg jelentôsége - intézményi, közösségi és egyéni felelôsség

A karakterek és a hozzájuk való igazodás vizsgálata után fontos a hatalomgyakorlás mechanizmusát, valamint az intézményi-közösségi felelôsségvállalás megjelenését tanulmányozni a három filmben. Amint az a zaklatás meghatározásakor is elhangzott, a tekintély és a hatalom kulcsfontosságú tényezôk a gyermek és felnôtt között létesülô szexuális viszonyokban, amelyekre a legtöbb esetben hierarchikus intézményi keretek adnak „lehetôséget”. A vizsgált filmek így az intézményi zaklatás különbözô közegeit mutatják meg, ahol általában a család szerepe is elôkerül, igen komplex problémává téve a felelôsségvállalás kérdését.
} 
A Kétely a már említett egyházi iskola közegében játszódik a hatvanas évek Amerikájában, melyegy igen specifikus politikai-társadalmi kontextust emel a zaklatás témája köré. Az egyházizaklatások botrányai az intézményes zaklatás egyik fố vonulatát adják, melyben egy többszörösen hierarchikus közeg jelenik meg, így nem véletlen, hogy a filmes reprezentációban az egyháziiskola erôsen tekintélyalapú intézménye is elókerül. A tekintély mellett azonban épp abizalmasabb viszony kialakítása adja Flynn atya esetén a vád alapját, holott ebben a szituációbantehát nincs szó zaklatásról. Az igazság azonban nem derül ki, ugyanakkor a pap büntetést sem kap,az egyház csak áthelyezi egy másik pozícióba, és nem hozza nyilvánosságra a történteket, ígyelfogadják és elrejtik a problémát, kibújva az ítélet és következmények felelőssége alól.

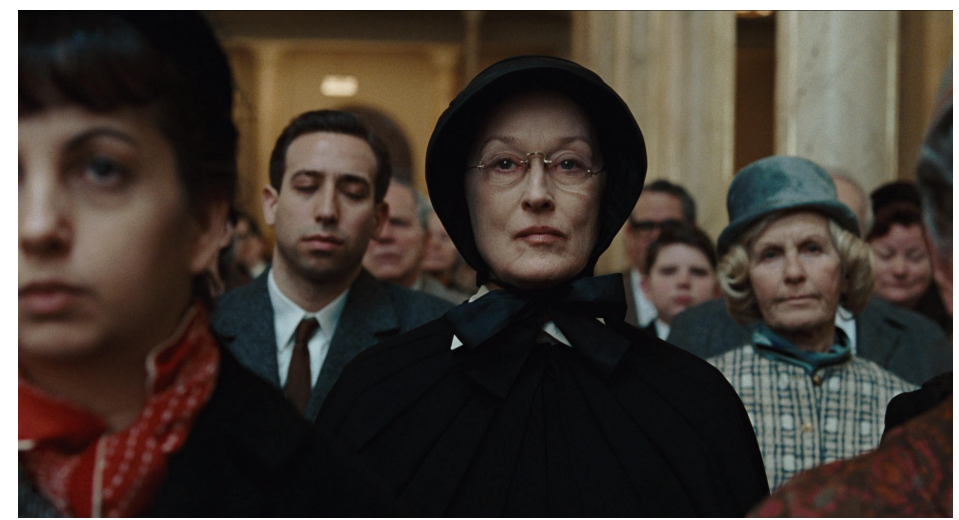

Kétely (Doubt. John Patrick Shanley, 2008)

A család felelôssége is felmerül Aloysius nôvér Donald anyjával való beszélgetésekor, amikor a nôvér megdöbbenve hallja, hogy az anya tud a feltehetôleg egészségtelen viszonyról. A nó úgy véli, hogy a gyermekének még így is jobb dolga van, mint otthon az elnyomó, homofób apja mellett, mely egyrészt egy emocionálisan érthetô érv, azonban mégis rámutat a családi felelôsség hárítására is, mely ellehetetleníti a probléma felismerését és kezelését. Következésképp az intézményi vagy családi szerepvállalásból egyéni „küldetés” lesz, ahogyan Aloysius nôvér küzd Flynn atya ellen. Ilyen értelemben pedig a nôvér tette és elszántsága dicséretre méltó, hiszen nem akarja hagyni, hogy rejtve maradjon a zaklatási ügy, a film azonban éppen arról szól, hogy jelen esetben egy ártatlan ember válik vádlottá egy olyan ügyért, amely egyébként valóban megtörténhet az adott közegben.

Az intézményes keret $A$ vadászat címú filmben is megjelenik, az óvodai környezet ugyanis szintén alapot adhat a zaklatásra, melyben a tekintélyt és dominanciát kihasználó személy hatalmat tud gyakorolni a manipulált gyermek felett. Emellett a film cselekménye egy nagyon zárt közösségben játszódik, ahol az ismeretség miatt az abúzus ténye még inkább felháborítja a lakókat, akik összefogva lépnek fel a feltételezett elkövetô ellen. Az óvodáskorú Klara felelősségérôl nehezen beszélhetünk, azonban a közösségi szerepvállalás már sokkal fontosabb téma. Lucasnak a közösséggel szemben nincs is lehetôsége rendesen védekezni és elmagyarázni a történteket, a lakók ugyanis hamarabb taszítják ki maguk közül, gondolván, hogy végtére bárki, még a falu egy jól ismert, kedvelt tagja is követhet el ilyen szörnyú tettet. Ellenben Klara problematikus családi 
háttere fontos alapként szolgálhat arra nézve, miért akar a kislány ennyire bensôséges kapcsolatot ápolni Lucassal. Ezáltal a család szerepvállalásának hiánya is elôkerül a történetben, még ha nem is kifejezetten hangsúlyos módon. Továbbá a tévedés felelősségét is nehéz meghatározni, itt is a zárt közösség múködését okolhatjuk érte, mely - ahogyan az a zárójelenetból is kiderül - sosem fogja tudni teljesen visszafogadni az egyszer már kirekesztett fôszereplőt.

A történetben a sport adja azt a „közeget”, amelyben a fôszereplő gyerekként a lovagló- és futóedző áldozatává vált. A folyamatos flashbackek által megismerhetjük, miként került be ebbe a közegbe Jennifer, és hogyan építette ki a két edzố a lányban a közös bizalmat. Ennek következtében nézőként szemtanúi vagyunk a hatalomgyakorlás konkrét megnyilvánulásának, és egy olyan bizarr kapcsolat kialakításának, melyben közös titokként van jelen a gyermekkel folytatott szexuális viszony. A felelôsség kérdése pedig itt sem elhanyagolható: mint az már fentebb szóba került, az anya késôbb magát is hibáztatja a lányával történtekért, azonban a visszaemlékezésból nyilvánvalóvá válik, hogy a nố túlféltố szülôként épp a valódi bajt nem vette észre. Az elhanyagolt, nyárra a lovardába adott kislány így Mrs. G. személyében talált anyapótlékra, akihez hamarosan csatlakozott Bill is, mint a tekintélyt parancsoló férfi alakja. A család felelôssége tehát nagyon fontos lett volna a lány esetében, illetve a film felveti az edzéstársak potenciális sorstársi szerepét is. Jennifer felkeresi az annak idején vele együtt edzó lányokat, hogy tisztázzák a múltbéli eseményeket; ennek során ráébred, hogy több lány is az edzői zaklatás áldozata lehetett. Ez kinyitja az addig elszigeltnek tûnt eseményeket, és felhozza a csapattársak, illetve azok szüleinek felelôsségét is. A látottakból az is kiderül, hogy a múlt a legtöbbek számára homályos, és a zaklatás életkorbeli határai is elég képlékenyek, így a kicsit idôsebb korában szexuális viszonyba bevont lány például nem traumaként gondol az eseményekre. Az áldozatok és az ôket körülvevô közeg felelôssége tehát nagyon is problematikus, mely csak a múlt történéseinek feltárásával válik tisztázhatóvá. A tényleges elkövetôk pedig a fentiekben említett módon nem vállalnak szerepet ebben a tisztázásban, ôk is elfedik magukban az emlékeket, ezáltal is lehetséges az ilyen esetek titokban tartása.

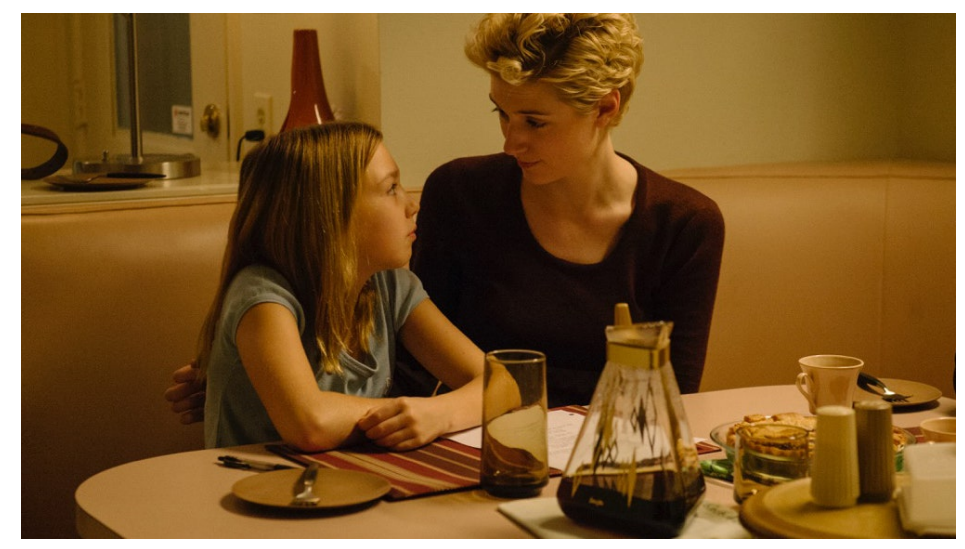

A történet (The Tale. Jennifer Fox, 2018)

Állásfoglalás és megoldási lehetôségek

Végül érdemes röviden áttekinteni, milyen állásfoglalások és lehetséges megoldási módok 
jelennek meg a fentebb tárgyalt filmekben. Alapvetôen megállapítható, hogy a Kétely és $A$ vadászat történetében a következmények bemutatása dominál, ahol az abúzus - mely valójában meg sem történt - csak kiváltó ok. A nézôpontok sokszínűsége is fontos jellemző, míg a Kétely és $A$ vadászat esetén a karakterek több nézôpontja és a szemtanúszerep erôsebben jelenik meg, addig $A$ történet inkább a személyes, „coming-of-age” alapú narratívára épít.

A Kétely állásfoglalását tekintve tehát elrugaszkodik a konkrét zaklatástól, és a hit, illetve meggyôződés kérdését helyezi a film középpontjába, így nem is hoz valódi megoldási lehetôséget, hiszen a vádak hatására csak áthelyezik az egyházon belül meggyanúsított papot. Ugyanakkor Flynn atya sorsa reprezentatív, mely önmagában is sokat elmond az egyházi zaklatási botrányok kezelésérôl, melyben a közösségi (egyházi és családi), valamint egyéni felelôsségvállalás kérdése egészen árnyaltan jelenik meg a karakterek motivációin keresztül. $A$ vadászatban szintén egy félreértett zaklatási botrányt látunk kibontakozni, melyben hatásosan vegyül a fôszereplô szubjektív (áldozativá váló) és a közösség kívülálló nézôpontja. Állásfoglalását tekintve így a film inkább a hamisan rágalmazott Lucas iránti empátiát erôsíti meg, és a közösség reakciói erôsen kritikusan jelennek meg. Ennek következtében a megoldási lehetôség itt sem múködô alternatíva, a zaklatási ügy kivizsgálása helyett ugyanis a személyes düh és agresszió kerekedik felül a közösségben. A történet a másik két filmmel szemben markánsabban foglal állást a konkrét zaklatással kapcsolatban, melyben a megoldást a fôszereplố traumával való szembenézése, valamint a tettesek szembesítése adja. Ezáltal a film utal ugyan az elkövetôk és a kívülállók (szülôk, edzéstársak) felelôsségére, azonban az áldozat „küzdelmét” helyezi a fókuszba, mely folyamat összetettségét példaértékúen mutatja be. Az explicit ábrázolásmód és a hatásos filmnyelvi megoldások pedig felkavarják és megrázzák a nézôt.

A bevezetésben taglaltak alapján elmondható, hogy a gyermekek szexuális bántalmazása egy rendkívül kényes, társadalmilag releváns probléma, melyet a köztudatban is gyakran övez tabusítás, ködös fogalmazásmód és nem tiszta állásfoglalás. Ebbôl kifolyólag a zaklatást feldolgozó alkotások esetén fontos értékelési szempont lehet, hogy a probléma mennyire komplex módon kerül bemutatásra, illetve hogy egy határozott vagy legalábbis tudatos állítás, állásfoglalás megjelenik-e az adott filmben. Ezáltal lehet ugyanis effektív módon bekapcsolódni az abúzust övezố társadalmi diskurzusba, állítást megfogalmazva és reagálva a témában elôkerülô fontosabb, megkerülhetetlen jelenségekre (például intézményi és szülői felelôsség).

A külföldi filmek rámutatnak a zaklatás témájának néhány feldolgozási lehetôségére, illetve a fenti elemzés támpontot is adhat arra nézve, hogy milyen szempontok alapján tudunk megítélni ilyen érzékeny és fontos kérdést feldolgozó alkotásokat. Éppen ezért fontos leszögezni azokat a kritériumokat, melyeket vizsgálva egységes összehasonlítást tudunk adni a magyar és külföldi feldolgozási módok között. A Kétely, A vadászat vagy A történet címú alkotások azért múködnek, mert a téma érzékeny és összetett megjelenítést kap, határozott tézist felmutatva a zaklatás tényét és megítélését illetôen. Van, hogy maga a konkrét szexuális zaklatás személyes megélése kerül a 
középpontba (1. A történet), de van, hogy a következmények bemutatásán keresztül látjuk az azt övezô társadalmi viselkedésmódokat, melyek esetén éppen a meg nem történt bántalmazás miatt válik igazán érdekessé a közeg reakciója (l. Kétely, A vadászat). A filmek múködôképességének, hatásosságának szempontjai tehát - a külföldi példákból kiindulva - a nézôpontok hiteles narratív múködtetése, az intézményi és családi közeg átható bemutatása, és az ezáltal kirajzolódó állásfoglalás lesznek, amely aspektusokat megvizsgáljuk a magyar filmek elemzésekor is.

\section{A zaklatás tematizálása a kortárs magyar filmben}

Amennyire fontos szerepet játszott a média a zaklatási ügyek köztudatba emelésében, legalább akkora mértékben negatívan is befolyásolta azt. Bár pozitív, hogy a szexuális zaklatás reprezentációja növekszik a különbözô felületeken, a közösségi média teret ad az internetes zaklatás (cyberbullying) különféle formáinak is. A következôkben vizsgált filmeket nézve egyértelmúen látszik, hogy mennyire kiszolgáltatottá válhatnak a bullying áldozatai, emellett a való életben is folyamatosan kerülnek elô tragédiákkal végződô történetek. Viszont mindenképp jó irány, hogy van felület a történtek bemutatásához, így mind a szexuális zaklatás, mind a bullying létezése kezd egyre inkább a köztudatba kerülni.

Az elemzett három magyar filmet [Szép csendben (Nagy Zoltán, 2019), FOMO: Megosztod és uralkodsz (Hartung Attila, 2019) és Remélem legközelebb sikerül meghalnod (Schwechtje Mihály, 2018)] tehát a kortárs nemzetközi filmek által felvázolt irányvonalak mentén elemezzük, mely szempontok alapján alapvetố különbségeket lehet felfedezni a külföldi és a magyar reprezentációs módok között. Három fố szempont mindhárom filmben kulcsfontosságú: a korosztályra jellemzô viselkedés (1), a közösségek múködése (2), a nézői azonosulás (3) mind a narratívák fontos mozgatóelemei. A felsorolásból kihagyható az elkövetôkre vonatkozó tettek következménye, ugyanis mindhárom film cselekménye kerüli a megoldást, amire a befejezések kifuthatnának, a búncselekmény elkövetését érdekesebbnek találják a magyar filmesek, mint a büntetést vagy a probléma hatékony kezelési lehetôségeinek felvázolását. Ez a hiány mindegyik filmben fontos szempont lehet mind az elemzésben, mind az értékelésben.

A filmek mélyrehatóbb vizsgálata előtt még fontos leszögezni, hogy a Szép csendben az egyetlen olyan elemzett magyar film, mely szorosan véve tematizálja a gyermekek szexuális zaklatását. Mindazonáltal ezen film mellett érdemes megvizsgálni további két olyan magyar példát, melyekben kiskorúak egymás közötti szexuális zaklatása jelenik meg, mivel azok szintén egy „coming-of-age” közegben játszódnak, fontos egyéni és közösségi mechanizmusokra rávilágítva. Így ez a két utóbbi film elsôsorban a bullying fogalmához köthetô, de egyelôre nem készült még olyan magyar film, amely felnôtt(ek) által elkövetett, gyerekeket érintố abúzust állítana narratívája középpontjába.

Szép csendben? 
Egy tehetséges, 14 éves csellistalány, Nóri, elmondja zenekari társának, Dávidnak, hogy tanáruk olyan módon közeledett felé, ahogyan nem kellene. A fiú mindenáron ki szeretné deríteni az igazságot, de a nagy tiszteletnek örvendô Frici bá' tetteit nehéz elhinnie az iskola nyilvánosságának, így tekintélye miatt elôször tagadásba fordul a tanári kar, de még az áldozat édesanyja is.

A rendezô, Nagy Zoltán azt nyilatkozta, hogy a megfigyelés szerint, amikor egy ilyen bûncselekmény történik, a való életben sem tudják pontosan a kívülállók, mi történt konkrétan, és ezt csak apró jelekból lehet összerakni. ${ }^{[25]}$ Szándéka szerint szembe szeretett volna menni azzal a médiában megszokott közlésmóddal, amely az esetekrôl a legmegrázóbb részleteket mutatja be, szélsôségesen jó és rossz szereplốk megjelenítésével. ${ }^{[26]}$ A rendezô álláspontját a pszichológusok is alátámasztják, miszerint az ilyen esetek a háttérben történnek, a filmet illetően így a nézó kénytelen minden lehetséges jelet megfigyelni és következtetéseket levonni, akár saját történetet is kitalálni, mert alapvetôen minden segítségtôl megfosztja a cselekmény.

Elôször is a filmben megjelenô karaktereket és nézôpontokat elemezve fontos, hogy jelen esetben a fôszereplô egy kívülálló személy, ami a külföldi filmekben is megszokott megoldás (l. Kétely). Ezáltal Dávid szemszögén keresztül követhetjük az eseményeket, ami egyúttal a nézô igazodását is megszabja, valamint a kívülálló karakter erkölcsi dilemmájába is betekintést ad, jó dramaturgiai kiindulópontot nyújtva. Ugyanakkor jelen esetben a narráció nem Dávid elsődleges szubjektív nézốpontját követi, csak mint központi karakterként múködteti, aki az összes zaklatásban érintett további szereplôvel kapcsolatban áll. Dávid nagyon is jó viszonyt ápol ugyanis az elkövetô Frigyessel, aki egyben a fiú tanítója, legjobb barátjának apja, anyja kollégája és egyben pótapaként is funkcionáló mentora, emellett Dávid anyja Frigyes felettese. Ebbe - az akár kissé mesterségesen összetettnek tûnő - viszonyrendszerbe „lép be” váratlanul Nóri, amikor megszólítja Dávidot.

Az áldozat szerepében megjelenô lányt ezután eleinte inkább Dáviddal történô interakciói során látjuk, azonban idôvel külön is válik Nóri szála Dávidétól, amikor például az órán vagy édesanyjával látjuk. Ez azért fontos, mert így kinyílik az eleinte szinte csak a fiúra (kívülállóra) koncentráló narráció, mely egyrészt elveszi a hangsúlyt a külsô nézốpont korlátozott tudásáról, ugyanakkor ezáltal a film Nóri szálát sem tudja igazán összetetten bemutatni a megosztott cselekményvezetés miatt.

Az áldozat családi háttere egyébként beleillik abba a statisztikába, mely szerint az egyedülálló szülók gyermekei nagyobb eséllyel vannak kitéve a szexuális zaklatásnak. ${ }^{[27]}$ Itt fontosak a narratív jelzések: az anya el van távolodva lányától, hétvégente egyedül hagyja, kezdetben nem is hisz neki, láthatóan hiányzik a szoros bizalmi kapocs közöttük. Nóri és Dávid ellentétek, utóbbi családja sem teljes, de szilárdabb, számíthat az anyjára, van párkapcsolata, közeli barátja (Frigyes fia). Nórinak emellett szembe kell néznie a bullyinggal is, ezért akár furcsán is hathat, hogy olyannak mondja el a vele történteket, akivel szintén nincs szorosabb viszonyban.

Az elkövetô, vagyis Frigyes alakja kifejezetten érdekesen jelenik meg a filmben, mivel a karakter 
iránt érzett szimpátia - mely Dávid szimpátiáján alapul - erôs kontrasztban áll a férfi által elkövetett zaklatással. Frigyesnél egyértelmúen jelenik meg a bevezetésben tárgyalt zaklató tagadása, ugyanis a férfi egészen a totális szembesítésig nem vállalja fel tettét, és nem ismeri be, hogy mit követett el. Mindazonáltal a férfi végsô reakciója az eseményekre, a valódi szembesítéskor tanúsított reakciója nem kap helyet a filmben, épp ott kerül elvágásra a cselekmény, ahol ez a nézôk elé tárulna. [28] Így azonban - A történetben látott elkövetôábrázoláshoz képest - Frigyes karakterének fontos fordulópontját nem mutatja meg a film, ezáltal végül nem is derül ki, milyen pozíciót vállal fel az elkövető ebben az igen komplex viszonyrendszerben.

A filmben megjelenô karakterek és nézôpontok tehát igen összetett képet rajzolnak ki, melyben a kívülálló domináns szemszöge mellett megjelenik az áldozat és az elkövetô perspektívája is. A külföldi filmpéldákkal ellentétben azonban Nagy Zoltán filmje nem tudja olyan eredményesen kihasználni sem a sok nézôpontot múködtetô narrációt, sem a kívülálló fốszereplôre koncentráló történetszálat. Utóbbi hiányát legfóképp a lezárás nyitott mivolta eredményezi, mely ugyan szabad alkotói döntésként értelmezhetô, azonban így az eredeti tét - Dávid erkölcsi dilemmája sem kap valódi kifutást a cselekmény szintjén. Emellett a cselekmény mindenáron a szexuális zaklatást próbálja a középpontba helyezni, de olyan fontos, a korosztály számára meghatározó részletek fölött siklik el egy-egy rejtélyes utalással, mint a bullying, a szerelem (Dávid és Klári kapcsolata, Dávid Nórinak adott csókja) vagy az ingatag családi hátterek.

A filmben bemutatott társadalmi környezetet vizsgálva az iskolai-zenei közeg sajátosan zárt közösségi volta miatt jó választás az intézményi zaklatás bemutatására. Azon belül is a magánórák olyan szituációt teremtenek, melyben az egészséges tanár-diák hierarchián alapuló viszony észrevétlenül kibillenthetô. Frici bá' bevált tanítási módszerei, mint például a barátságos közeg megteremtése (beszélgetések, labdázás) vagy a kezek tartásának beállítása alapvetően nem szexuális indíttatásúak, mivel elengedhetetlenek a zenéléshez szükséges könnyedség elôhívásához. A nézô pedig nem kap ennél több információt, Dáviddal együtt csak annyit tudunk, amennyit Nóri elmesél, ezért nehéz eldönteni, hogy ténylegesen átlépett-e egy határt a tanár vagy sem. ${ }^{[29]} \mathrm{A}$ masszírozás, masszíroztatás vagy a rágózás mind olyan védjegyei Frigyesnek, amelyet tanítványai az imázs részeként fogadnak el. Éppen ezért nehéz határvonalat húzni a progresszív és bizalmat építô tanár módszerei és a szexuális zaklatás kezdeti formái között, melyre épp Nóri utal egy kulcsfontosságú mondatával, amikor az órán való felcsattanásakor tanárának kimondja: „mert öleléssel kezdôdik”. 


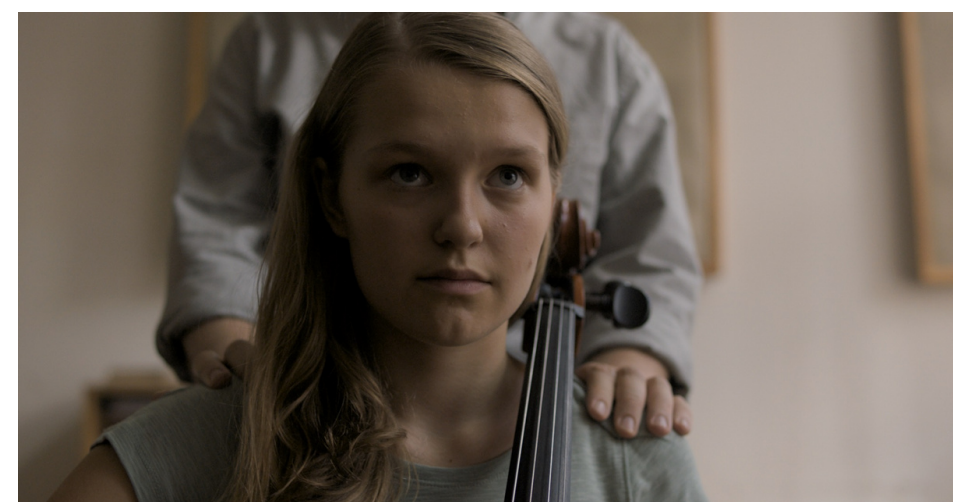

Szép csendben (Nagy Zoltán, 2019)

A hierarchia is fontos tényezó a Szép csendben esetén, ugyanis az megjelenik a zenekaron belül, a diákok és a tanár kapcsolatában, valamint a szülốk és a gyerekek között is. Nóri zenekarba kerülésével egy másik csellista a háttérbe szorul, a zenekar és a diákok külön-külön is teljesítik Frigyes kéréseit, továbbá az (elsôsorban) anya-gyerek helyzet is alá- és fölérendelt státuszt teremtenek.

Fontos lehet a közösség múködéséhez köthetô elemeket is megvizsgálni a filmben: Anne M. Nurse az edzôk és a sportolók közti szexuális zaklatás kapcsán említi, hogy az áldozatok nem mernek fellépni az elkövetôk ellen, mert félnek, hogy azzal veszélybe sodornák a közösségüket. ${ }^{\left[{ }^{30]} \mathrm{A}\right.}$ zenekar esetében, miután már néhány ember tudomást szerzett az ügyrôl (szülôk, tanárok), mindez elkezd kihatással lenni a közös utazásokra, illetve a magánórákba vetett bizalom is megrendül (Nóri édesanyja megnéz egy órát). Ugyanakkor Nóri szintén tagadásba kezd, melyet motiválhat a közösség védelme, hiszen Dávid szemszögén keresztül láthatjuk is, hogy a hír elterjedésével a zenekar mint bizalmi közösség létezése valóban veszélybe kerül.

Adott tehát egy hiteles intézményi közeg, melynek múködésébe bepillantást kapunk nézőként; a külföldi példák mentén érdemes röviden megvizsgálni a film által bemutatott közeg reakcióit és felelôsségvállalás kérdését, mivel a rengeteg szereplô és összetett viszonyrendszer kifejezetten indokolttá is teszi ezt. A közeg reakcióját tekintve valószerú az eltussolást bemutató helyzet, melyben a felelôsségvállalás kérdése is megjelenik mind Dávid, mind pedig édesanyja esetében. Ugyanakkor a cselekmény szintjén nem kap valódi hangsúlyt az eltussolás folyamata, mely ebben az ebben az esetben - ha már a kezelési mód egyáltalán nem kerül elő - kifejezetten érdekes lenne. Így a gyorsan elintézettnek látszó botrány már nem hat olyan reálisan (és érdekesen), ami szintén hozzájárul a nyitott vég problematikusságához. Emellett azonban hatásosan jelenik meg a szülői felelôsség kérdése Nóri anyukájának realizálási folyamatával; a lány beszélgetése a nyomozati bíróval és édesanyjával hủ a valósághoz: egy kiskorú gyermeket csak szülői jelenléttel hallgathatnak ki.

A filmet különösen visszafogott stílus jellemzi, melyhez hozzájárul a lassú történetvezetés is. Ebben a korosztályra jellemző közösségi média-használat szinte egyáltalán nem jelenik meg, ami kifejezetten szokatlan megoldás, kevésbé korhúvé is téve a megjelenített „” narratívába helyezkedô közeget. A telefon például csak egyszer kap szerepet, a hangfelvétel készítésekor, minden más 
szóban hangzik el - lassítva a történtek lefolyását -, valamint látszólag Nórit is csak személyesen piszkálják társai. A visszafogottság alkotói elvének korlátai a zárlatban ütköznek ki talán a leginkább, a zárómondat („Köszönöm, de elég volt”) hatásos ugyan, de nem vált ki indulatokat még az asztalnál ülókben sem. A kérdôre vonás is annyira kódolttá válik így, mint maga a bûn elkövetése, így a cselekmény végére a történtek egyetlen következménye Dávid csalódása, amit több filmkritikában is hiányosságként rónak fel [Vajda Judit például emiatt aSzép csendbent félkész filmnek is nevezi. ${ }^{[31]}$

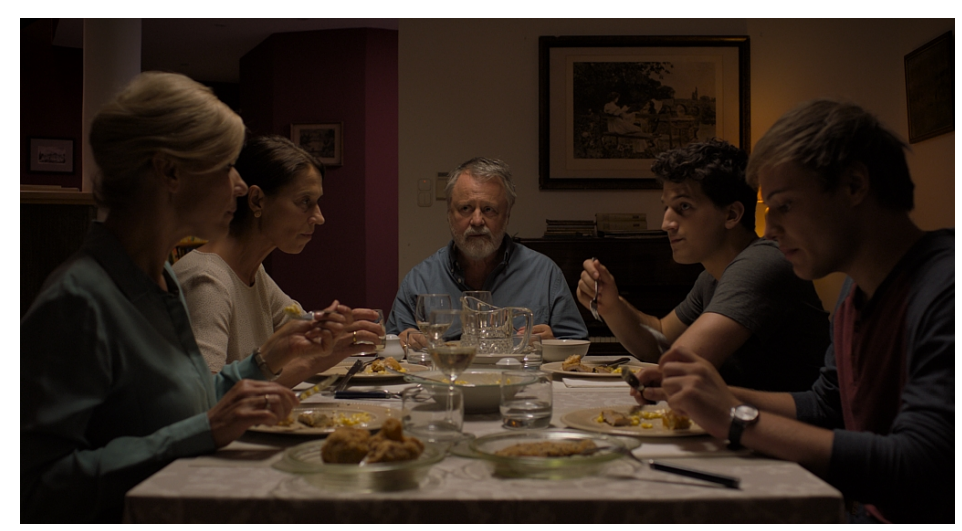

Szép csendben (Nagy Zoltán, 2019)

Összességében a film reprezentációs stratégiáit vizsgálva megállapíthatjuk, hogy a Szép csendben egyrészt jó eszköztárból dolgozik a karakterek és a nézôpontok szintjén, másrészt az intézményi szerepvállalás tekintetében hitelesen mutatja be az eseményeket. Az alkotás egy zaklatási eset látleletét adja, melyet valós társadalmi kontextusba is elhelyez, azonban a külföldi példákkal ellentétben nem megy ennél tovább, a nyitott lezárás miatt nem kapunk konkrét állítást vagy épp állásfoglalást a zaklatás kényes témájában. A fontos dramaturgiai-cselekménybeli elemek (például az eltussolás folyamata) kihagyása és a minimalista, visszafogott narratív stílus által így túlságosan távolságtartó lesz a zaklatás egyébként is ködösített témájával.

FOMO és Remélem legközelebb sikerül meghalnod ? Áldozat és elkövetố a „coming-of-age”-narratívákban

A Szép csendben-hez hasonlóan ez a két film is az iskolai közeghez köti a zaklatásokat, akkor is, ha nem feltétlenül a középiskola a helyszín. A FOMO-ban egy fiúcsapat (Falka) YouTube-tartalmakat gyárt, amelyekben esztelen és felesleges kihívásokat teljesítenek. Egy házibuliban addig győzködik társukat, amíg meg nem erôszakolja az egyik tanáruk - alkoholtól - magatehetetlen lányát, Lillát. Az elkövetô, Gergố, bûntudattal kezd küzdeni, végül mindent félredobva beismeri búnét a lánynak.

A Remélem legközelebb sikerül meghalnod -ban Eszter és barátnôje plátói szerelmet éreznek fiatal tanáruk iránt, aki az egyik órán bejelenti, hogy külföldre költözik a családjával. A diákok összetörnek, búcsúbulit rendeznek, ahol Eszter és a tanár között elindul a flörtölés, online üzenetek formájában. A profil mögött végig Eszter osztálytársa áll, aki betegesen vágyakozik a lány után (álprofil létrehozása, pizsama ellopása). Bizalmába férkőzik, félmeztelenre vetkőzteti a webkamera elôtt, majd féltékenységében szétküldi a róla készült fotókat az osztályban. 
Hartung Attila filmje az elkövetôn, Schwechtje Mihályé az áldozaton keresztül múködteti a narratívát, azzal a különbséggel, hogy a FOMO-ban a szubjektív kameraállások sokkal közelebb engedik a nézốt az eseményekhez, elôsegítve a lelki folyamatok ábrázolását, melyre a film nagy hangsúlyt fektet. A megdermedô idố a legötletesebb módja lett egy „másik dimenzió” létrehozásának (családi fotó készítése, aluljáró-jelenet), hiszen a jelentől Gergó elidegenedett, a bûncselekmény után elkezdi megkérdôjelezni önmaga és a Falka döntéseit is. Személyiségük miatt Patrik közülük a leginkább vezetô típus, a többiek pedig elsôsorban az ô ötleteit, véleményét követik, még akkor is, amikor látszólag közösen találnak ki dolgokat. Bár látszólag egyenértékúek a Falka tagjai, a csapathierarchia fontos mozgatóeleme a történéseknek, csapatként csak addig múködóképesek, amíg ugyanazt gondolják a történtekrôl, és egyikük érdeke sem sérül. Emiatt tud kialakulni a nézôben az átrendeződés a karakterek iránt érzett szimpátia szempontjából, ugyanis azon a ponton, ahol Gergố már kész bevallani tettét, a nézô erôsen elkülöníti ốt a Falka többi tagjától. Ugyan ô az elkövetô, és tettei súlyossága alól nem ad felmentést a film, azonban ettôl a ponttól fogva már nem az erôszaktevô a legkevésbé szimpátiát keltố személy. Ez nyilvánvalóan adódik abból a tudatos döntésbôl is, hogy a film egyértelmú fôszereplöje Gergô, az elkövetô, akinek bûnhôdési folyamatával azonban mégiscsak sikerül a filmnek egyfajta együttérzést kivívnia a nézô részérôl. [32]

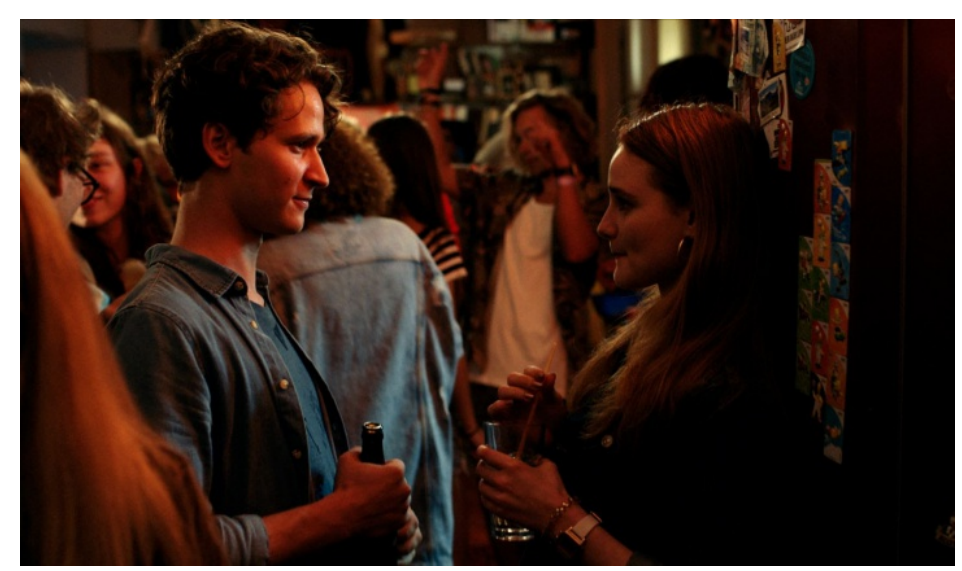

FOMO: Megosztod, és uralkodsz (Hartung Attila, 2019)

A Remélem... játékidejének elsô felében elsôsorban Eszter szálát követjük, majd a nézô elôtt leleplezôdô álprofil után Eszter és Péter szinte ugyanolyan hangsúlyt kap. A FOMO-val ellentétben viszont Péter - mint elkövető - teljes ellenszenvet kelt, folyamatosan szándékosan rossz döntéseket hoz, ezzel egyre jobban belesodródik a saját hazugságai labirintusába. Megjelenik a kegyetlen oldala is, amikor az utcán hagyja a lánytól kapott kutyát, de lop és manipulál is. Mindkettôjüknél felbukkan a borotvapenge, öngyilkosságot végül Eszter próbál elkövetni. A felvezetés aprólékosságához képest az öngyilkosság nem kap érzelmi mélységet, a lányt érô sorozatos csalódások egyik pillanatról a másikra, kapkodva vezetnek a film tetôpontjához. A kórházi jelenet bár megrázó, Péter ekkorra már annyira negatív karakter, hogy nem lehet következtetést levonni, milyen érzelmek kavaroghatnak benne, amiért meglátogatta a lányt.

A családi hátterek az elôző filmekhez hasonlóan szintén nem elmélyítettek, de a Szép csendben-nel 
ellentétben nem mellékszálként jelennek meg, hanem rövid jelenlétükkel hozzátesznek a karakterek motivációjához és jellemrajzához. Eszter édesanyja egyedülálló és randizik, de igyekszik bizalmi kapcsolatot fenntartani lányával. Péterékhez éppen akkor költözik be az új mostohaapa, aki átveszi a felelôs szülô szerepét, míg az anya szinte teljesen eltúnik a hétköznapokból. A FOMO Gergője mögött egy befolyásos család áll, ami kelló indok ahhoz, hogy az iskolaigazgató minél diszkrétebben akarja elrendezni az ügyet. Mindkét filmben dicséretes, hogy számolnak a közösségi médiával, ami nem engedi, hogy eltúnjenek a bizonyítékok, így az esetek hírei nem tudnak az iskolán belül maradni. Schwechtje Mihály filmje az iskolai közösség hierarchiájára épít, ahol a diákok féltik saját hírnevüket, és a FOMO-hoz hasonlóan azért tesznek meg dolgokat, hogy feljebb lépjenek a ranglétrán. Ilyen például Beni karaktere, aki többször is elmondja, hogy a szakítások miatt csökken a tekintélye a közösségben.

A Remélem... kórházi jelenete nem ad egyértelmú választ arra, hogy Péter mire lenne még képes, vagy mennyire tudatosult benne saját önzése. A szoknyát felhúzó Beni ellenben mind az iskolában, mind otthon felelôsségre lett vonva. Az apja és a közte lévő éles hierarchikus viszony verbálisan és fizikálisan is fel van építve, ugyanakkor érdekes, hogy ez a zaklatás, ami miatt az elkövetô ténylegesen kapott valamilyen büntetést, nem tett kárt komolyabban a lányban. Bár az iskolai közeg megjelenik mindkét filmben, és a FOMO-ban ezt bonyolítja az is, hogy az áldozat apja tanár, egyik filmben sem jelenik meg hangsúlyosan az intézményi felelôsségvállalás kérdése. Ezekben az esetekben ez nem kelt erôs hiányérzetet, mivel a cselekmény végig a zaklatást - és annak lelki hatásait - tartja meg központi narratív szálnak.

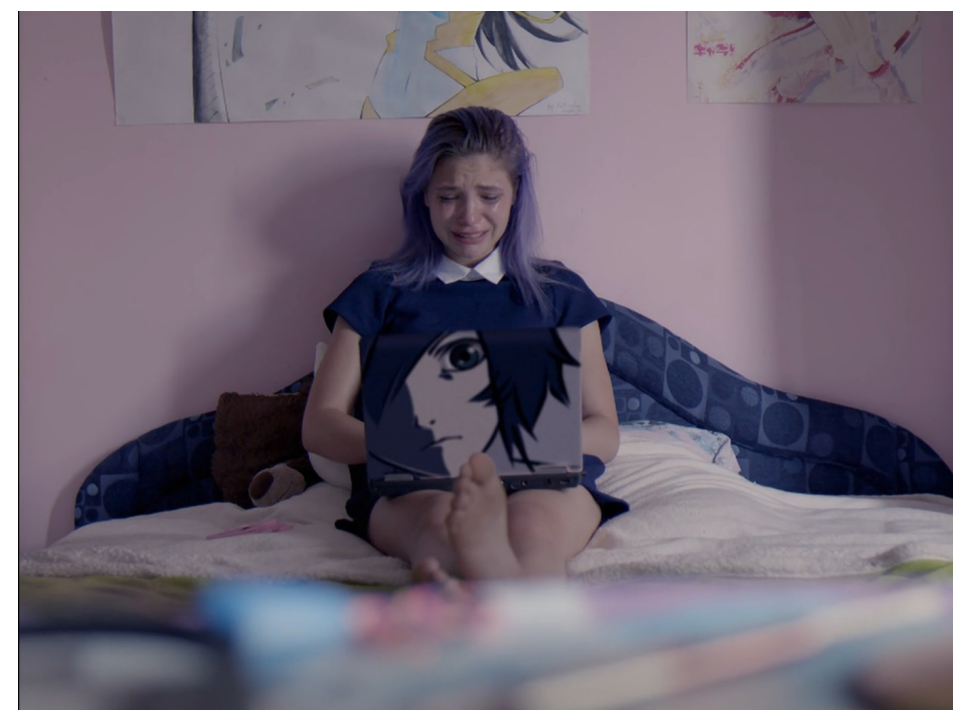

Remélem legközelebb sikerül meghalnod (Schwechtje Mihály, 2018)

Közös vonás, hogy mindkét filmben egyértelmúen megtörténik a búncselekmény, a Remélem... késlelteti ugyan, de az Esztert érintô egyre súlyosabb nyomásgyakorlás megelólegezi a „kapcsolat” rossz végkimenetelét. A lány kétféle zaklatás áldozata is lesz, az egyik a szexuális zaklatás fizikai megjelenése (egy osztálytársa felhúzza a szoknyáját az iskola folyosóján), a másik pedig szexuális tartalommal való visszaélés online térben (érzelmi zsarolás, majd bullying). Péter, az utóbbi elkövetôje folyamatosan visszaigazolást vár a kölcsönös érzelmekrôl, amikor ezt meggyengülni 
látja, követel, számonkér. Az alacsony önbecsülés a szexuális zaklatásokat elkövetôk között magas arányban jelenik meg, amit szexuális kontaktussal igyekeznek kompenzálni. [33]

Meg kell említenünk a zaklatás gender-vonatkozásait is. Mindhárom elemzett magyar filmben férfi, illetve fiú zaklat, és fiatal lány az áldozat, de nem szabad megfeledkezni róla, hogy ezek csak egy-egy, többé-kevésbé fiktív (Szép csendben) esetet mesélnek el a saját cselekményvilágukban és a valóságban fiúk is lehetnek ilyen események áldozatai.

Példás, hogy a magyar filmesek gyorsan és méltósággal tudnak a szexuális zaklatás ügyével foglalkozni, de egyelôre a tendencia azt mutatja, hogy egy ilyen búncselekmény elkövetésének folyamata érdekesebb, mint a megoldása. A FOMO készítôi bizonyították be talán leginkább, hogy nagyon jól lehet a sokkot, búntudatot ábrázolni filmes eszközökkel, de egyelöre nincs igazán példa arra, hogy a következmények hogyan hatnak az emberek érzéseire, legyen szó az áldozatról, az elkövetôrôl vagy egy nagyobb közösségrôl.

\section{Konklúzió}

A fent tárgyalt magyar, illetve külföldi filmek a gyermekek szexuális zaklatásának gazdag filmes feldolgozási lehetôségeit szemléltetik. Továbbá azt is, hogy milyen eltérô tétje lehet annak a döntésnek, hogy a filmek hogyan foglalnak állást a zaklatás valóságosságát illetôen, vagy, hogy kik között és milyen közegben történik az abúzus, illetve, hogy mennyire mutatja meg a film a következményeket, az esetleges állásfoglalási lehetôségeket. A magyar és külföldi példákat vizsgálva alapvetôen megállapítható, hogy a magyar filmekben kevésbé reprezentált a felnôtt zaklató, a három említett filmbốl a felnôtt által elkövetett abúzust csak a Szép csendben tematizálja. Ugyanakkor a bullying jelensége és a fiatalok közti zaklatás témája különösen erôsen jelenik meg a kortárs magyar filmben, mely mindenképp fontos és társadalmilag is elôremutató tendencia. Emellett viszont a tettes büntetése vagy bûnhődése - és így a megoldás, a feloldás vagy a probléma kezelésének lehetôségei - szinte egyáltalán nem kerül elô, míg a külföldi filmeknél a Kétely és $A$ vadászat is fókuszba emeli a vélt elkövetô „tett” utáni sorsát, nyomatékossá téve a büntetés folyamatának bemutatását. Ezáltal az ábrázolt intézményi-családi közeg reakciói, viselkedési mintái is fontos szerephez jutnak, árnyalva az adott társadalmi-kulturális környezet bemutatását.

Mi adja tehát a zaklatás témájának hatásos és hiteles feldolgozását? Elsôsorban a benne és körülötte résztvevô személyek és szerepek hiteles és összetett ábrázolása, melyhez vagy több nézôpontot (elkövetô-áldozat-kívülálló) kell jól múködtetni vagy egyet mélységében bemutatni (l. A történet). A Szép csendben a karakterek egészen összetett viszonyrendszerét vázolja fel, azonban egyszerre próbálja a korlátozott tudású kívülálló szerepét a középpontba helyezni, miközben mégsem mélyül el benne, aminek egyik oka épp az áldozat szálának finom beemelése. Ezáltal azonban a motivációk is nehezebben érthetôk, mely problémára jó példaként szolgálhat a Dávid és Nóri között hirtelen kialakuló gyengéd érzelmi viszony. Megfigyelhetô, hogy a Szép csendben esetén 
mind a „coming-of-age”-narratíva, mind pedig a szemtanú-szerep megjelenik, azonban épp az elôbb említett hiányosságok és furcsaságok miatt végül egyiket sem tudja kellóképpen kibontani a film. Ugyanakkor a FOMO és a Remélem... jobban múködô aránnyal használja a nézôpontok komplexitását, és a Szép csendben-nel együtt nézve mindenképp jó tendencia, hogy különböző narratív megoldásokkal élnek a kortárs magyar filmes példák.

Fontos a zaklatás körüli közeg bemutatása is, melynek hitelességétôl függhet, hogy áll vagy bukik az adott alkotás. A közösség reakciója, kezelési módjai, illetve az intézményi felelősség kibontása mind olyan elemek, melyek hiányai nagy ûrt hagynak a nézóben egy ilyen alkotás esetén. A közösségi felelősség összetettségét a Kételynek és $A$ vadászatnak kifejezetten komplex módon sikerül megmutatnia, talán éppen azért is, mert nagy hangsúlyt fektetnek a kialakuló botrány körüli reakciók és következmények megmutatására. A Szép csendben esetén a közeg és kortárs valóság hiteles ábrázolása nagyon fontos erôssége a filmnek, azonban a felelôsség összetettségének kérdése mind az iskolai, mind a szülöi oldalon csak finoman jelenik meg benne, a lezárást követô események még nagyon érdekes és fontos aspektusát adhatták volna a zaklatási botránynak. A Szép csendben erôsebben be van ágyazva az iskolai közegbe, mint a másik két magyar film, de egyik sem mutat be következményeket, pedig az hasznukra lehetett volna a narratívák árnyalásában.

Végül pedig fontos, hogy az adott alkotás miként foglal állást a megmutatott ügy kapcsán, vagyis, hogy hova fut ki a zaklatás témájának feldolgozása. A nemzetközi filmes példákban mind felfedezhetô egy erôs állítás, egy tétel, amely mentén felépítik az adott filmet. Ez lehet személyes meggyőzôdés és a hit ereje egy zaklatási botrány ügyében (1. Kétely), a zárt közösségből elôhozott embertelen reakció megmutatkozása egy ilyen ügy kapcsán (l. A vadászat) vagy éppen egy gyermekkori bántalmazás miatt eltemetett trauma szubjektív feldolgozása (1. A történet). A Szép csendben esetén megjelenik a föszereplô személyes erkölcsi dilemmája, valamint az iskolai közeg problémamegoldásának kérdése is, azonban éppen a film szerzőibb hangulatú, finom(kodó) narratív stílusa gátolja meg ezeknek a valódi mélységekben való ábrázolását. A túl sok nézôpont múködtetése és a nyitott vég együttesen vezetnek ahhoz a problémához, hogy a film kezdeti tétje gyengül, majd teljesen elveszni látszik. A visszafogott fogalmazásmód ugyanis könnyen teheti súlytalanná ezt az egyébként igen súlyos témát. Közös a Remélem....-ben és a FOMO-ban, hogy a felnövekedési alaphelyzetet kihasználva sajátos filmnyelvvel élnek (közösségi média vizuális megjelenítése). Gergố (a FOMO elkövetôje) iránt empátiát próbál a narratíva elóidézni, ami feloldás nélkül ér véget, Péter (a Remélem... elkövetôje) családi hátterével alátámasztott szemszöge pedig szintén különleges megoldás.

És hogy mi a tétje egy ilyen film múködôképességének és eredményességének? Jenny Kitzinger szerint a médiafigyelemnek - legyen szó televíziós, dokumentarista vagy fikciós narratíváról alapvetố befolyása van arra nézve, hogyan gondolkodnak, mit mondanak és mit éreznek elutasíthatónak az emberek. Ezáltal a szexuális bántalmazás médiában (és filmben) való megjelenése teljesen megváltoztatta a témáról való diskurzust, sokkal nyíltabbá tette azt, ami hatással lehet a túlélôk identitásának felépítésére, a párbeszéd elindítására és a jövô lehetôségeinek 
meglátására is. ${ }^{[34]}$ Egy-egy múködô és hatásos film tehát nagy horderôvel bírhat ebben a diskurzusban, emiatt is fontosak a szexuális zaklatás témájának feldolgozására vállalkozó alkotások. Mindazonáltal a tény, hogy ebbe a tendenciába több kortárs magyar film is bekapcsolódott, mindenképp reményt keltô és elôremutató.

\section{Jegyzetek}

1. Davidson, Julia C.: Child Sexual Abuse: Media Representations and Government Reactions. New York, Routldge [] Cavendish, 2008. 6.

2. Child Sexual Abuse. RAINN - The nation's largest anti-sexual violence organization, URL: https://www.rainn.org/articles/child-sexual-abuse , 2021. 10. 05.

3. Davidson, Julia C.: i. m. 20.

4. Nurse, Anne M.: Confronting Child Sexual Abuse: Knowoledge to Action. Lever Press, 2020. 71.

5. Rowen, Edward L.: Understanding Child Sexual Abuse. Jackson, University Press of Mississippi

6. Nurse, Anne M.: i. m. 80.

7. Uo. 79-80.

8. Rowen, Edward L.: i. m. 25-26.

9. Nurse, Anne M.: i. m. 44.

10. Wright, Katie: Speaking Out: Representations of Childhood and Sexual Abuse in the Media, Memoir and Public Inquiries. Red Feather Journal: An International Journal of Children in Popular Culture, 7.2. 17-30.

11. Davidson, Julia C.: i. m. 25.

12. Nurse, Anne M.: i. m. 37-40.

13. Uo. 41.

14. Nurse, Anne M.: i. m. 43.

15. Wright, Katie: i. m. 17-19.

16. Wright, Katie: i. m. 19.

17. Todd Taylor: Cinematic representations of boyhood sexual abuse, 1967-2006. Doktori disszertáció. Canberra, University of Canberra, Faculty of Arts and Design, 2011. 31-47.

18. Uo. 201. Itt pedig a szerzô itt olyan filmeket említ meg, mint például a Vissza a jövốbe (Back to the future. Robert Zemeckis, 1985), Pillangó-hatás (The butterfly effect. Eric Bress, J. Mackye Gruber, 2004) vagy a $z$ Egy botrány részletei (Notes on a scandal. Richard Eyre, 2006).

19. Malone, Peter: The Abuse of Minors: A Cinema Resource. Compass, 2005, 39.4. 31.

20. Uo. 31 .

21. Nurse, Anne M.: i. m. 28.

22. Wright, Katie: i. m.

23. A filmben továbbá megjelenik az felnôtt nôii zaklató személye is, aki jelen esetben egy lány gyermeket zaklat, mely egy általában kevésbé reprezentált abuzív viszony.

24. Davidson, Julia C.: i. m. 59.

25. Csatlós Hanna: „Attól zengett a média, hogy az elkövetô hányszor és hova nyúlt be, miközben nem ez a lényeg". hvg.hu, 2019. 11. 22. URL: https://hvg.hu/kultura/20191122_Nagy_Zoltan_szep_csendben_film_interju_metoo

26. Nurse, Anne M.: i. m. 37. 
27. Uo. 79 .

28. Pontosabban a lezárás elốtt már megtörténik az igazgatónô (Dávid édesanyja) által a szembesítés, azonban ebben az esetben is épp ott ér véget a jelenet, ahol Frigyes rákérdez, hogy mitévôk legyenek most.

29. Uo.

30. Nurse, Anne M.: i. m. 68.

31. Vajda Judit: Szólamhatár. Filmvilág, 2019. december. URL: https://filmvilag.hu/xereses_aktcikk_c.php?\&cikk_id=14347\&gyors_szo=\%257CFOMO\&start=0

32. Taylor, Todd: i. m. 196.

33. Davidson, Julia C.: i. m. 74.

34. Kitzinger, Jenny: Transformations of Public and Private Knowledge: Audience Reception, Feminism and the Experience of Childhood Sexual Abuse. In Memory Matters: Contexts for Understanding Sexual Abuse Recollections. Szerk. Janice Haaken - Paula Reavey. London, Routledge, 2010. 95-96.

\section{Irodalomjegyzék}

- Child Sexual Abuse. RAINN - The nation's largest anti-sexual violence organization, 2021. 10. 05. URL: https://www.rainn.org/articles/child-sexual-abuse

- Csatlós Hanna: „Attól zengett a média, hogy az elkövető hányszor és hova nyúlt be, miközben nem ez a lényeg". hvg.hu, 2021. 08. 14. URL: https://hvg.hu/kultura/20191122_Nagy_Zoltan_szep_csendben_film_interju_metoo

- Davidson, Julia C.: Child Sexual Abuse: Media Representations and Government Reactions. New York, Routldge [Cavendish, 2008.

- Kitzinger, Jenny: Transformations of Public and Private Knowledge: Audience Reception, Feminism and the Experience of Childhood Sexual Abuse. In Memory Matters: Contexts for Understanding Sexual Abuse Recollections. Szerk. Janice Haaken - Paula Reavey. London, Routledge, 2010. 95-96.

- Malone, Peter: The Abuse of Minors: A Cinema Resource. Compass, 39. 4. 2005. nyár. URL: http://compassreview.org/summer05/7.html

- Nurse, Anne M.: Confronting Child Sexual Abuse: Knowledge to Action. Lever Press, 2020.

- Rowen, Edward L.: Understanding Child Sexual Abuse. Jackson, University Press of Mississippi, 2006.

- Todd Taylor: Cinematic representations of boyhood sexual abuse, 1967-2006. Doktori disszertáció. Canberra, University of Canberra, Faculty of Arts and Design, 2011.

- Vajda Judit: Szólamhatár. Filmvilág, 2019/12. 12-13. december. URL: https://filmvilag.hu/xereses_aktcikk_c.php?\&cikk_id=14347\&gyors_szo=\%257CFOMO\&start $=0$

- Wright, Katie: Speaking Out: Representations of Childhood and Sexual Abuse in the Media, Memoir and Public Inquiries. Red Feather Journal: An International Journal of Children in Popular Culture, 7.2. 17-30.

\section{Filmográfia}

- A történet (The Tale. Jennifer Fox, 2018) 
- A vadászat (Jagten. Thomas Vinterberg, 2012)

- Az utolsó mozielóadás (The Last Picture Show. Peter Bogdanovich, 1971)

- Diploma elótt (The Graduate. Mike Nichols, 1967)

- Egy botrány részletei (Notes on a Scandal. Richard Eyre, 2006)

- FOMO: Megosztod, és uralkodsz (Hartung Attila, 2019)

- Kétely (Doubt. John Patrick Shanley, 2008)

- Pillangó-hatás (The Butterfly Effect. Eric Bress, J. Mackye Gruber, 2004)

- Remélem legközelebb sikerül meghalnod :) (Schwechtje Mihály, 2018)

- Szép csendben (Nagy Zoltán, 2019)

- Szívzörej (Le soufflé au cœur. Louis Malle, 1971)

- Vissza a jövóbe (Back to the future. Robert Zemeckis, 1985) 
(c) Apertúra, 2021. nyár | www.apertura.hu

webcím: https://www.apertura.hu/2021/nyar/olah-varga-mert-olelessel-kezdodik-a-gyermekekszexualis-zaklatasanak-reprezentacioja-kortars-magyar-es-kulfoldi-filmekben/

https://doi.org/10.31176/apertura.2021.16.4.9

(Q) opertúro 